\title{
PERANCANGAN KAMPANYE KOMUNIKASI KALENDER \\ TANAM (KATAM) DALAM UPAYA ADAPTASI \\ PERUBAHAN IKLIM
}

\author{
Abdul Aziz ${ }^{1}$,Muhamad Isnaini ${ }^{1}$, Nahri Idris ${ }^{1}$, Yuhdi Fahrimal ${ }^{1}$, Mohammad \\ Alhabieb Alhafidz ${ }^{2}$ \\ ${ }^{1}$ Program Doktor Komunikasi Pembangunan Pertanian dan Pedesaan IPB \\ ${ }^{2}$ Program Magister Komunikasi Pembangunan Pertanian dan Pedesaan IPB \\ ayizhar@yahoo.com, emisnaini@gmail.com, fahrimalhazmi@gmail.com
}

\begin{abstract}
Background of this review is the fact that the campaign of Information System of Integrated Planting Calendar/KATAM has been done on a massive scale. Notwithstanding, just many peasant know and use KATAM as a guideline.Purpose of this reviewis to determine the design of KATAM communication campaigns. Thisreview using secondary data,then analyzed with AISAS method. The results show, the communication through the campaign on KATAM basically already done by Balitbangtan. The campaign was carried out by using the internet and social media. KATAM campaign is quite effective. Further study need to be done to determine share of KATAM to others.
\end{abstract}

Keywords: campaign, communication, planting calendar

\begin{abstract}
ABSTRAK
Latar belakang kajian ini adalah fakta bahwa Sistem Informasi Kalender Tanam Terpadu/KATAM telah dikampanyekan secara masif dan dimanfaatkan untuk pengaturan pola tanam, pemilihan varietas, dan rekomendasi pupuk. Namun, hal tersebut belum membuat petani di Indonesia mengetahui dan memanfaatkan KATAM sebagai pedoman bercocok tanam padi dan palawija. Tujuan kajian ini adalah untuk mengetahui rancangan kampanye komunikasi KATAM kepada para penyuluh pertanian dan petani. Kajian ini dilakukan dengan cara pengumpulan data-data sekunder yang diperoleh dari Balitbangtan dan studi literatur dari berbagai sumber buku bacaan dan jurnal. Data yang diperoleh selanjutnya dianalisis dengan model komunikasi Lasswell. Sedangkan proses kampanye KATAM dianalisis dengan metode AISAS. Hasil kajian menunjukkan, komunikasi melalui kampanye tentang KATAM pada dasarnya sudah dilakukan oleh Balitbangtan. Kampanye ini dilaksanakan dengan menggunakan media internet dan media sosial. Kampanye KATAM ini cukup efektif karena berdampak pada banyaknya pengunjung website KATAM pada periode tertentu.
\end{abstract}


Agar lebih meyakinkan apakah keberhasilan kampanye KATAM, perlu dilakukan kajian tentang share bagi konsumen/pengguna KATAM kepada orang lain.

Kata kunci: kampanye, komunikasi, kalender tanam

\section{PENDAHULUAN}

Tujuan utama komunikasi adalah tersampaikannya pesan dari pengirim kepada penerima. Pesan itu baik berupa informasi maupun bujukan. Pengiriman pesan tersebut dilakukan melalui bermacam-macam cara dan alat. Melalui mulut ke mulut maupun menggunakan media atau secara tertulis maupun lisan (Mulyana, 2000).

Selain untuk menginformasikan kepada orang lain, tujuan komunikasi juga untuk mempengaruhi orang lain agar dapat berubah perilakunya. Komunikasi persuasi ini biasa dilakukan dalam bentuk kampanye. Kampanye dilakukan untuk menyampaikan pesan informasi kepada orang lain dengan tujuan untuk mengajak dan mempengaruhi penerima pesan agar melakukan sesuatu sesuai dengan pesan kampanye dimaksud.

Kampanye sebagai suatu kegiatan komunikasi yang menurut beberapa ahli didefinisikan sebagai kegiatan yang dilakukan oleh individu atau organisasi untuk menyampaikan pesan informasi kepada khalayak secara terencana, bertahap, dan terkadang suatu saat memuncak yang bertujuan untuk mempengaruhi sikap, pendapat, dan opini seseorang atau massa (Setiani, 2007). Rogers dan Storey (1987), dalam Setiani (2007) mendefinisikan kampanye sebagai serangkaian tindakan komunikasi yang terencana dengan tujuan menciptakan efek tertentu pada sejumlah besar khalayak yang dilakukan secara berkelanjutan pada kurun waktu tertentu. Parrot dalam Ruslan (2000) menjelaskan bahwa kampanye merupakan kegiatan komunikasi yang dilakukan secara terencana pada waktu tertentu dengan tujuan untuk mempengaruhi dan membujuk khalayak. Proses komunikasi ini memiliki tujuan memberikan pengaruh supaya khalayak menjadi terbujuk dan melakukan sesuatu dari apa yang dikampanyekan.

Menurut William J Mc Guire dalam Setiani (2007) mengemukakan bahwa komponen komunikasi dalam proses kampanye ada lima macam yaitu sumber, pesan, channel, faktor penerima, dan tujuan. Hal ini senada dengan yang diungkapkan Lasswell dalam Nimo (2011) yang menggambarkan bahwa proses komunikasi dan fungsi-fungsi yang diemban dalam masyarakat terdiri dari who, says what, in which channel, to whom, and with what effect.Variabel sumber komunikasi persuasif mengacu pada karakteristik individu maupun organisasi yang 
seolah-olah menghadirkan pesan bagi publik. Pesan merupakan suatu variabel yang terkait dengan isi dari informasi yang disampaikan oleh komunikator kepada penerima pesan. Variabel channel harus dilakukan melalui media komunikasi baik lisan, cetak, maupun elektronik seperti TV, radio, internet, dan media sosial. Variabel faktor penerima meliputi individu maupun kelompok yang akan menerima pesan. Sedangkan variabel tujuan merupakan perubahan perilaku yang terjadi pada target atau sasaran dari kampanye.

Teknologi komunikasi semakin berkembang dengan pesat sehingga banyak konsumen yang mengalami perubahan dalam menemukan informasi seperti komunikasi online, telepon genggam, dan media digital. Menurut Sugiyama dan Andree dalam Puspita (2012) menyatakan bahwa konsumen telah mengalami perubahan secara mendasar yang disebabkan oleh perkembangan pesat komunikasi online, telepon genggam, dan media digital. Hal ini yang mendasari internet marketing semakin berkembang dan diminati oleh konsumen karena melalui internet dapat terwujud komunikasi dua arah. Selain itu juga media sosial seperti Facebook, Twitter, dan WA dapat membuat komunikasi dua arah yang efektif sehingga semakin banyak yang menggunakannya.

Dengan banyaknya pengguna internet dan media sosial, maka berkembanglah suatu konsep komunikasi yang dikembangkan oleh Dentsu Inc. yang disebut sebagai Attention-Interest-search-ActionShare (AISAS). AISAS dibuat untuk merefleksikan atas besarnya peranan internet terhadap kehidupan manusia sekarang ini (Puspita, 2012).

Indonesia merupakan salah satu negara dengan penduduk yang mencapai lebih kurang 250 juta jiwa sehingga berdampak pada konsumsi beras yang cukup besar. Untuk memenuhi kebutuhan beras nasional bagi penduduk Indonesia diperlukan produksi dan produktivitas tanaman padi secara berkelanjutan sebagai manifestasi dari kemandirian pangan yang kuat. Langkah kebijakan, taktis, dan operasional pencapaian kemandirian pangan diantaranya dituangkan dalam bentuk program Peningkatan Produksi Beras Nasional (P2BN), serta dalam bentuk target Empat Sukses Pembangunan Pertanian. Dalam upaya pencapaian Empat Sukses Pembangunan Pertanian, peran Penelitian dan Pengembangan Pertanian sangat penting dan vital, yaitu melalui penciptaan teknologi inovasi, baik berupa varietas unggul baru, prototipe atau model sistem usaha tani dan perekayasaan, teknologi sistem informasi, teknologi budidaya, pascapanen serta alat dan mesin pertanian, termasuk pula didalamnya adalah model diseminasi dan kelembagaan. Pemanfaatan teknologi tersebut telah terbukti nyata dapat meningkatkan 
produktivitas pertanian. Salah satu produk unggulan Badan Penelitian dan Pengembangan Pertanian (Balitbangtan), yang dikampanyekan secara masif dan dimanfaatkan untuk pengaturan pola tanam, pemilihan varietas, dan rekomendasi pupuk adalah Sistem Informasi Kalender Tanam Terpadu/KATAM (Sarwani dan Syahbuddin, 2013). Disamping itu, Balitbangtan juga diberi tugas melalui Permentan Nomor 45 Tahun 2011 untuk melakukan pengawalan dan pengamanan produksi beras nasional (P2BN) yaitu dengan menyiapkan dan mengembangkan KATAM untuk menjadi rujukan pelaksanaan P2BN di daerah (Kushartanti, et.al, 2013).

Meskipun telah dilakukan upaya sosialisasi yang cukup signifikan,teratur, dan terus menerus, hingga saat ini, belum $100 \%$ petani di Indonesia mengetahui dan memanfaatkan KATAMsebagai pedoman bercocok tanam padi dan palawija.Selain hambatan sarana dan prasarana teknologi informasi,ketersediaan saprodi (benih, pupuk, pestisida, alat mesinpertanian) tepat waktu, distribusi ketersediaan tenaga kerja, danmodal, menjadi kendala rutin bagi petani sebelum memulaibercocok tanam (Sarwani, dan Syahbuddin, 2013). Penelitian yang dilakukan oleh Kushartanti, et.al. (2013) bahwa hasil evaluasi penerapan KATAM terpadu di Jawa Tengah yaitu dari 106 petugas yang mengikuti sosialisasi KATAM terpadu terdapat 75 orang pernah mendengar informasi KATAM. Dari jumlah tersebut, 25 petugas pernah mengoperasikan KATAM dan enam orang pernah menerapkan KATAM yang terkait dengan rekomendasi varietas. Hasil penerapan pada rekomendasi varietas tersebut menunjukkan bahwa KATAM belum maksimal sampai kepada petani.

Salah satu usaha yang perlu dilakukan agar petani mendapat informasi tentang KATAM dan mempengaruhi petani untuk mengikuti pola tanam yang direkomendasikan oleh KATAM yaitu dengan membuat kampanye yang ditujukan kepada para penyuluh pertanian dan petani. Menurut Setiani (2007) bahwa kampanye dapat menunjukkan pengaruh yang besar dalam mengubah sikap khalayak. Namun demikian, strategi kampanye KATAM ini belum pernah dilakukan baik dari pemerintah pusat yang dalam hal ini adalah Balitbangtan maupun pemerintah daerah terkait. Oleh sebab itu tujuan kajian ini adalah untuk mengetahui rancangan kampanye komunikasi KATAM kepada para penyuluh pertanian dan petani.

\section{KERANGKA PEMIKIRAN \\ Strategi Komunikasi Program Pembangunan}

Menurut Rogers, komunikasi merupakan perpanjangan tangan para 
perencana pemerintah dan fungsi utamanya adalah untuk mendapatkan dukungan masyarakat dan partisipasi mereka dalam pelaksanaan rencanarencana pembangunan (Rogers dan Shoemaker 1981). Dari pendapat Rogers ini jelas bahwa setiap pembangunan dalam suatu bangsa memegang peranan penting. Karenanya pemerintah dalam melancarkan komunikasi perlu memperhatikan strategi apa yang dapat digunakan untuk menyampaikan pesan sehingga efek yang diharapkan itu sesuai dengan harapan.

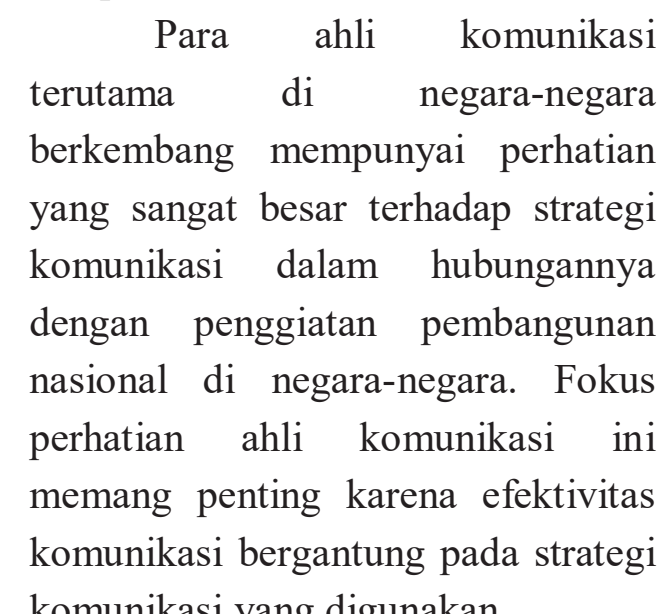
komunikasi yang digunakan.

Effendy (1993) mengatakan strategi baik, secara makro (planned multimedia strategy) mempunyai fungsi ganda yaitu:

a. Menyebarluaskan

pesan

komunikasi yang bersifat informatif, persuasif, dan instruktif secara sistematik kepada sasaran untuk memperoleh hasil yang optimal.

b. Menjembatani "cultural gap" akibat kemudahan diperolehnya dan kemudahan dioperasionalkannya media massa yang begitu ampuh, yang jika dibiarkan akan merusak nilai-nilai budaya

Strategi pada hakikatnya adalah perencanaan (planning) dan manajemen untuk mencapai suatu tujuan. Akan tetapi untuk mencapai tujuan tersebut, strategi tidak berfungsi sebagai peta jalan yang menunjukkan arah saja, melainkan harus menunjukkan bagaimana taktik operasionalnya. Dengan demikian strategi komunikasi merupakan paduan dari perencanaan komunikasi (communication management) untuk mencapai suatu tujuan. Untuk mencapai tujuan tersebut strategi komunikasi harus dapat menunjukkan bagaimana operasionalnya secara taktis harus dilakukan, dalam arti bahwa pendekatan (approach) bisa berbeda tergantung pada situasi dan kondisi.

Untuk mantapnya strategi komunikasi, maka segala sesuatunya harus dipertautkan dengan komponen-komponen yang merupakan jawaban terhadap pertanyaan yang dirumuskan, yaitu who says what in which channel to whom with what effect. Rumus tersebut jika dikaji lebih jauh, pertanyaan "efek apa yang diharapkan" secara implisit mengandung pertanyaan lain yang perlu dijawab dengan seksama, yaitu: 1. When (Kapan dilaksanakannya). 2. How (Bagaimana melaksanakannya). 3. Why (Mengapa dilaksanakan 
demikian). Atau dalam ilmu jurnalistik sering dikatakan dengan $5 \mathrm{~W} 1 \mathrm{H}$ (what, who, why, when, where, dan how).

Para ahli komunikasi sependapat bahwa dalam melancarkan komunikasi lebih baik mempergunakan pendekatan yang disebut $A$-A Procedure atau from Attention to Action Procedure. AA Procedure adalah penyederhanaan dari suatu proses yang disingkat AIDDA (attention[perhatian], interest[minat],

desire[kemauan/hasrat],

decision[keputusan], action [tindakan]). Jadi proses perubahan sebagai efek komunikasi melalui tahapan yang dimulai dengan membangkitkan perhatian. Apabila perhatian komunikan telah terbangkitkan, hendaknya disusul dengan upaya menumbuhkan minat, yang merupakan derajat yang lebih tinggi dari perhatian. Minat adalah kelanjutan dari perhatian yang merupakan titik tolak bagi timbulnya hasrat untuk melakukan suatu kegiatan yang diharapkan komunikator. Hanya ada hasrat saja pada diri komunikan, bagi komunikator belum berarti apa-apa sebab harus dilanjutkan dengan datangnya keputusan, yakni keputusan untuk melakukan tindakan. Selain melalui pendekatan di atas, maka seseorang komunikator harus mempunyai kemampuan untuk melakukan perubahan sikap, pendapat, dan tingkah laku apabila dirinya terdapat faktor-faktor kredibilitas dan attractiveness.

\section{Strategi Komunikasi Efektif}

Strategi komunikasi yang efektif dalam komunikasi pembangunan tidak hanya sekadar membuat pesan-pesan yang bisa memberikan dampak bagi target ataupenerimapesan. Tapi juga mampu merefleksikan misi, tujuan, dan sasaran organisasi yang terintegrasi dalam operasi seharihari. Maka, strategi itu butuh artikulasi yang jelas tentang penerimapesan, kejelasan pesan dan pilihan media.

Adapun strategi yang efektif dalam penyampaian komunikasi pembangunan antara lain:

\section{a. Planning}

Strategi komunikasi yang
efektif selalu diawali oleh perencanaan yang solid dan matang (planning) yaitu kunci bagi keberhasilan proyek tujuan. Perencanaan yang bagus bisa dijadikan koridor kerja bagi orangorang yang melaksanakan misi komunikasi. Strategi akan membimbing kita kearah mana komunikasi digerakkan, mulai dari proses persiapan hingga menyampaikan pesan pada publik.

\section{b. Sasaran dan Tujuan}

Pesan harus diciptakan sejelas-jelasnya demi sasaran yang dituju, lalu pesan disampaikan dengan metode yang tertentu supaya bisa sampai ke publik yang kita 
bidik. Untuk mencapai target ini, tentu dibutuhkan teknologi pembantu agar penyusunan planning jadi lebih mudah.

Karenanya sasaran dan tujuan harus ditetapkan saat melakukan planning yaitukhalayaksiapa yang ingin dijangkau, bagaimana keadaankhalayak sasaran yang hendak dijangkau, mengidentifikasi khalayak dan kemudian memahami keadaan khalayak. Ini adalah salah satu kunci keberhasilan rencana komunikasi yang baik dan efektif. Karena komunikasi yang efektif bukan berarti harus menjangkau semua target penerimapesan. Tapi lebih efektif jika kita bisa membidik orang-orang tertentu yang sangat berpengaruh dalam pembuatan keputusan publik.

\section{c. Pembentukan Pesan}

Pembentukan pesan dengan sedemikian rupa sehingga menjadi perhatian publik juga menjadi salah satu strategi efektif dalam komunikasi untuk mencapai tujuan yang diinginkan. Kita harus bisa menyusun pesan yang cocok untuk berbagai kalangan khalayak sasaran dan berbagai bentuk media yang digunakan.

Karenanya setelah berhasil mengidentifikasi penerimapesan, baru membentuk pesan-pesan yang akan disampaikan pada penerimapesan. Pesan-pesan ini harus terkait kuat dengan misi organisasi dan tujuan komunikasi.
Dalam membentuk pesan, perlu mempertimbangkan hal-hal berikut: seberapa besar khalayak kita, pesan model apa yang lebih gampang direspons oleh khalayak, melalui media apakhalayak bisa dicapai (internet, radio, TV, cetak), informasi apa yang dibutuhkankhalayak dari organisasi kita, bahasa apa yang akan lebih gampang ditangkap khalayak, dan saat merancang pesan kita juga harus perhatikan bahwa setiap media komunikasi (televisi, cetak, email, web) akan membutuhkan pendekatan berbeda.

\section{d. Pilihan Media}

Memilih jenis media yang paling cocok untuk menyampaikan pesan dan menjangkau penerimapesan merupakan langkah yang harus diambil. Karena jika tepat, penerimapesanakan sangat cepat memahami pesan yang diberikan. Jenis media yang dipilih akan berpengaruh pada kemampuan penerimapesanmenjangkau isi pesan.

Jenis media tertentu mungkin bisa menyampaikan pesan tertentu dan bisa dijangkau kelompok penerimapesantertentu pula. Juga patut kita perhatikan dalam mengemas pesan format harus disesuaikan bisa dikemas dalam bentuk berita, hiburan, atau bahkan iklan.

\section{e. Evaluasi}

Strategi komunikasi yang efektif selalu mempertimbangkan evaluasi, namun yang satu ini sering 
kali terabaikan. Bisa jadi pengabaian ini berdasarkan fakta bahwa sebagian besar evaluasi berlangsung di bagian akhir dari suatu proses. Kalau hasilnya bagus, orang cenderung tidak melakukan evaluasi, tapi kalau hasil akhirnya kurang bagus baru orang berpikir tentang evaluasi.

Padahal evaluasi itu penting agar kita bisa mendapatkan feed back sesegera mungkin. Hasil akhirnya bagus atau tidak, kita tetap butuh feed back.Kalau hasil akhirnya bagus,feed back bisa digunakan untuk perumusan strategi komunikasi mendatang. Kalau hasil akhirnya tidak bagus maka feed back bisa dijadikan rujukan agar tidak mengulanginya.

Untuk mengevaluasi strategi komunikasi, bisa dilakukan dengan cara mengumpulkan data kuantitatif dan informasi kualitatif. Untuk kuantitatif, pertanyaan yang harus kita jawab adalah seberapa banyak target penerimapesan yang sudah dijangkau via media. Untuk kualitatif, pertanyaan yang harus kita jawab adalah apakah pesan punya dampak yang diharapkan terhadap target penerimapesanatau tidak. Ini bisa berlaku saat kita menggunakan semua jenis media dan semua kondisi penerimapesan. Namun yang agak sulit adalah mengukur perubahan perilaku pada target penerimapesan.

\section{Persuasi Program Pembangunan}

Menurut David K. Perry, kampanye secara umum adalah contoh persuasi dalam sebuah aksi. Aksi tersebut tidak akan menarik ketika hanya memaparkan data-data saja tanpa diolah, dikemas secara menarik mata dan juga menggugah afeksi target penerimapesandari kampanye ini. Kampanye juga merupakan bentuk persuasi. Persuasi adalah sebuah proses transaksional diantara dua orang atau lebih dimana terjadi upaya merekonstruksi realitas melalui pertukaran makna simbolis yang kemudian menghasilkan perubahan kepercayaan, sikap, dan atau perilaku secara sukarela (Venus, 2012).

Dalam persuasi, ada beberapa hal yang perlu diperhatikan, yakni:

a. Penetapan Komunikator

Komunikator merupakan pemegang peranan yang paling strategis dalam komunikasi. Ada tiga syarat yangharus dipenuhi seorang komunikator, yakni: (1) tingkat kepercayaan orang lain kepada dirinya (kredibilitas), (2) dayatarik (attractive), dan (3) kekuatan (power)

b. Penetapan Target Sasaran

Masyarakat merupakan subyek sekaligus obyek yang menentukan bagaimana keberhasilan dari penyelenggaraan suatu program. Oleh karena itu, komunikator harus memahami lebih dahulu karakteristikmasyarakat. Untuk memahami karakteristik masyarakat, 
komunikator dapat melakukan dahulu. Segmentasi masyarakat dapat dilakukan dengan cara memetakan karakteristik masyarakat. Untukmengetahui pemetaan khalayak dapat diperoleh dari survei, analisis isi media, kecenderungan parlemen, focusgroup, dan open forum.

\section{c. Penyusunan Pesan}

Pesan sangat bergantung pada program yang mau disampaikan. Program penyuluhan untuk penyadaranmasyarakat maka sifat pesannya harus persuasif dan edukatif. Selanjutnya yang perlu diperhatikan dalam menyusun pesan, apabila program yang dipasarkan sifatnya tidak nyata maka memerlukan penjelasan yang lebih lengkap, mudah dimengerti, dan memberikan prospek apa yang akan diperoleh setelah menerima program tersebut.

d. Media dan Saluran Komunikasi

Memilih media komunikasi harus mempertimbangkan karakteristik isi dan tujuan isi pesan yang ingin disampaikan, dan jenis media yang paling banyak diakses oleh khalayak.

\section{METODE PENELITIAN}

Kajian ini menggunakan pendekatan kualitatif. Metode yang digunakan adalah deskriptif. Data yang dihimpun melalui data sekunder yang diperoleh dari
Balitbangtan dan studi literatur dari berbagai sumber buku bacaan dan jurnal. Data yang diperoleh selanjutnya dianalisis dengan metode komunikasi Lasswell. Sedangkan proses kampanye KATAM dianalisis dengan metode AISAS.

\section{HASIL DAN PEMBAHASAN}

Sistem Informasi Kalender Tanam Terpadu

Badan Penelitian dan Pengembangan Pertanian (Balitbangtan) merupakan suatu lembaga pemerintah di lingkungan Kementerian Pertanian yang mempunyai mandat untuk melakukan penelitian, pengembangan, dan inovasi di bidang pertanian (Kementan, 2015). Teknologi yang dihasilkan oleh Balitbangtan telah banyak dimanfaatkan oleh petani untuk meningkatkan produksi di bidang pertanian. Selain itu Balitbangtan juga telah mendiseminasikan teknologi yang telah dihasilkan kepada masyarakat pertanian. Sistem Informasi Kalender Tanam Terpadu (KATAM) merupakan salah satu bentuk teknologi yang dihasilkan Balitbangtan yang telah diterapkan hingga ditingkat kecamatan seluruh Indonesia (Ramadhani, et.al., 2013).

KATAM merupakan suatu inovasi baru yang dihasilkan Balitbangtan. Inovasi merupakan sesuatu yang berkaitan dengan barang, jasa, atau gagasan yang dirasakan baru oleh seseorang 
maupun orang banyak. Tanpa adanya inovasi suatu organisasi atau perusahaan tidak akan berlangsung lama karena kebutuhan, keinginan, dan permintaan pengguna yang selalu dinamis (Hadiyati, 2011). Inovasi yang dihasilkan Balitbangtan juga harus memperhatikan kebutuhan pengguna terutama petani di seluruh wilayah yang mempunyai karakteristik spesifik lokasi.

Balitbangtan, sejak 2007 telah menyusun atlas kalender tanam untuk padi sebagai panduan waktu tanam bagi penyuluh dan petani di setiap kecamatan di seluruh Indonesia. Estimasi awal waktu tanam ditentukan berdasarkan kondisi curah hujan tahunan yaitu pada kondisi basah, normal, dan kering. Apabila sifat iklim tahunan suatu kecamatan tersebut basah maka lahan sawah kecamatan tersebut diasumsikan mengalami kondisi basah sepanjang tahun, padahal iklim bersifat dinamis sepanjang tahun. Prakiraan sifat iklim BMKG untuk setiap zona musim menunjukkan hasil yang berbeda antarmusim (Balitbangtan, 2015).

Peran strategis KATAM dalam adaptasi perubahan iklim tercermin dari kemampuan sistem informasi ini dalam menginformasikan kondisi musim tanam ke depan, yang meliputi awal waktu tanam tanaman pangan, wilayah rawan bencana banjir, kekeringan, dan organisme pengganggu tanaman (OPT), serta rekomendasi teknologi berupa varietas, benih, dan pemupukan berimbang. KATAM berbasis web pertama kali diluncurkan secara resmi oleh Kepala Balitbangtan pada 27 Desember 2011 dengan diterbitkannya secara online KATAM ver 1.0 yang memuat informasi kalender tanam terpadu Musim Tanam I (MT-I) 2011/2012. Sejak saat itu, KATAM ver 1.0 telah diperbarui lima kali serta diperbaiki dan disempurnakan (Runtunuwu, et.al., 2013).

Saat ini informasi yang terdapat dalam KATAM terdiri dari delapan macam. Pertama adalah standing crop yang menyediakan luas tanam padi sawah per fase pertumbuhan (vegetatif 1 , vegetatif 2, generatif 1, generatif 2) tiap kecamatan seluruh Indonesia berdasarkan citra MODIS. Kedua, monitoring CCTV yaitu untuk memverifikasi dan memvalidasi KATAM, telah dilakukan pemasangan 55 monitoring online KATAM CCTV di tujuh provinsi (Lampung, Banten, Jabar, Jateng, DIY, Jatim, dan Bali). Ketiga, estimasi luas tanam yaitu untuk musim tanam ke depan merupakan informasi yang sangat dibutuhkan oleh petani. Keempat, status kerawanan banjir dan kekeringan tingkat kabupaten. Kelima, status organisme pengganggu tanaman (OPT) yaitu untuk menggambarkan serangan hama OPT di suatu wilayah kabupaten. Keenam, penentuan rekomendasi varietas dan prakiraan 
kebutuhan benih. Ketujuh, rekomendasi dan kebutuhan pupuk yakni mendeskripsikan jenis pupuk yang diperlukan pada setiap kecamatan, dan yang kedelapan adalah mekanisasi pertanian yang merupakan informasi tentang kesiapan sarana pertanian seperti traktor, thresher, dan yang lainnya, baik untuk kebutuhan maupun kekurangan serta usaha pemenuhan alat tersebut (Ramadhani, et.al., 2015).

Sistem aplikasi KATAM terpadu telah berkembang pesat yang semula dari dua subsistem (aplikasi web dan desktop) menjadi sistem yang lebih komprehensif yaitu menjadi tujuh subsistem, yang terdiri dari aplikasi web KATAM, aplikasi desktop KATAM, aplikasi SMS center, aplikasi Androidversi ringan, aplikasi entri data melalui Google Drive, aplikasi desktop pemantauan KATAM, dan aplikasi web pemantauan KATAM. Pengembangan aplikasi ini untuk mempermudah mengakses data dan informasi dari tingkat pusat sampai ke petani. Kemudahan pengguna untuk mengakses data KATAM dari tingkat pusat sampai dengan petani melalui beberapa jalur komunikasi diharapkan dapat menurunkan kegagalan petani akibat perubahan iklim (Ramadhani, et.al., 2015).

\section{Analisis Komunikasi Kampanye} KATAM

Proses komunikasi dalam mengampanyekan KATAM perlu dilakukan analisis komunikasi sehingga dapat diketahui model komunikasi yang terdapat dalam kampanye tersebut. Lasswell dalam Nimmo (2011) mengemukakan bahwa cara yang mudah untuk melukiskan suatu tindakan komunikasi yaitu dengan menjawab pertanyaan siapa (who), mengatakan apa (says what), dengan saluran apa (in which channel), kepada siapa (to whom), dan dengan akibat apa (and with what effect).

\section{Siapa (what)}

Kata siapa biasanya menunjuk kepada kata benda yang mampu berbuat sesuatu dalam mengomunikasikan kepada orang lain. Dalam hal ini biasanya adalah individu atau kelompok tertentu yang menyampaikan pesan kepada penerima pesan. Individu atau kelompok ini disebut sebagai komunikator atau dalam model komunikasi yang dibuat Rogers disebut sebagai sumber.

Aktor yang berperan sebagai sumber dalam proses komunikasi kampanye KATAM dilakukan secara birokrasi. Hal ini agar mempunyai kekuatan dan kekuasaan dari pemerintah baik pusat maupun daerah untuk mendukung kelancaran program ini. Dengan kekuatan dan kekuasaan pemerintah diharapkan 
semua user khususnya petani dapat memanfaatkan dan mengimplementasikan KATAM secara berkelanjutan. Sumber informasi dalam proses komunikasi kampanye inisecara institusi ada tiga yaitu Balitbangtan, Balai Pengkajian Teknologi Pertanian (BPTP) sebagai penyambung lidah di daerah,dan pemerintah daerah baik provinsi maupun kabupaten/kota.

Peran dari masing-masing sumber berbeda satu dengan yang lainnya. Peran Balitbangtan adalah sebagai penghasil inovasi teknologi KATAM yang sekaligus sebagai sumber utama informasi tentang KATAM. Sedangkan peran BPTP adalah sebagai sumber kedua setelah mendapat informasi KATAM dari Balitbangtan. Disamping itu BPTP juga mengoordinasikan baik internal maupun dengan pemerintah daerah setempat untuk melaksanakan program KATAM, mengumpulkan data hasil verifikasi dan validasi kondisi lapangan yang selanjutnya disampaikan kepada tim Katam pusat, serta menyosialisasikan KATAM di tingkat pemerintah daerah, penyuluh, dan petani, serta melakukan advokasi pada dinas pertanian atau lembaga terkait agar KATAM dapat dijadikan salah satu program daerah khususnya dibidang pertanian. Selanjutnya peran dari pemerintah daerah yaitu sebagai penerima dan sekaligus sebagai sumber dalam program KATAM. Sebagai penerima, karena pimpinan daerah mendapat sosialisasi tentang KATAM dari Tim Gugus Tugas KATAM yang dikomandoi oleh BPTP dan sebagai aktor karena dengan kekuatan dan kekuasaannya pemerintah daerah dapat memerintahkan seluruh jajaran dan instansi terkait untuk melaksanakan program KATAM.

\section{Mengatakan apa (says what)}

Dalam proses komunikasi seseorang atau individu mendefinisikan makna yang disampaikan sesuai dengan perbuatan dan imajinasinya secara simultan dan timbal balik. Secara sederhana seseorang akan menanggapi rangsangan berdasarkan persepsi dan interpretasinya terhadap rangsangan yang disampaikan. Rangsangan yang membantu timbulnya pencitraan itu adalah pesan yakni mengatakan apa (Nimmo, 2011). Pesan yang disampaikan harus jelas sehingga dapat menimbulkan persepsi yang sama diantara yang berkomunikasi.

Dalam kasus KATAM yang menjadi pesan dimulai dari salah satu program prioritas nawacita pemerintah yaitu meningkatkan produktivitas rakyat dan daya saing di pasar internasional sehingga bangsa Indonesia bisa maju dan bangkit bersama bangsa-bangsa Asia lainnya (Zubaidah, 2015). Penjabaran dari program tersebut dituangkan dalam kebijakan pembangunan pertanian 2015-2019 
yang dibuat oleh Kementan yang salah satunya adalah adaptasi dan mitigasi perubahan iklim serta penanganan pascabencana alam. Kebijakan Kementan tersebut ditindaklanjuti oleh Balitbangtan dengan membuat inovasi teknologi KATAM untuk mengantisipasi perubahan iklim terhadap penurunan hasil pertanian.

KATAM bersifat dinamik karena informasinya disusun dengan mempertimbangkan hasil interpretasi prakiraan curah hujan dan prakiraan awal musim dari BMKG. Informasi yang dihasilkan pada sistem informasi ini, antara lain hasil prediksi curah hujan dan awal musim, prediksi awal musim tanam, pola tanam, luas tanam potensial, dan intensitas tanam. Istilah 'terpadu' dimunculkan karena disamping informasi-informasi tadi, KATAM juga menampilkan informasi tentang rekomendasi dosis pupuk, rekomendasi kebutuhan pupuk, varietas padi eksisting, rekomendasi varietas padi, potensi serangan OPT, serta informasi potensi kerawanan banjir dan kekeringan.

Peran strategis KATAM dalam adaptasi perubahan iklim tercermin dari kemampuannya dalam menginformasikan kondisi musim tanam ke depan, yang meliputi awal waktu tanam tanaman pangan, wilayah rawan bencana banjir, kekeringan, dan organisme pengganggu tanaman (OPT), serta rekomendasi teknologi berupa varietas, benih, dan pemupukan berimbang. KATAM berbasis web pertama kali diluncurkan secara resmi oleh Kepala Badan Litbang Pertanian pada 27 Desember 2011 dengan diterbitkannya secara online KATAM versi 1.0 yang memuat informasi KATAM Musim Tanam I (MT-I) 2011/2012. Sejak saat itu, KATAM versi 1.0 telah diperbarui lima kali serta diperbaiki dan disempurnakan (Runtunuwu, 2013).

\section{Dengan saluran apa (in which channel)}

Bagian dari lima serangkaian model Lasswell ini menyangkut media yaitu dengan melalui saluransaluran apa. Hal ini dikarenakan saat ini banyak keragaman media yang digunakan orang dalam berkomunikasi (Nimmo, 2011). Komunikasi dapat disampaikan melalui berbagai media seperti cetak, noncetak, elektronik, dan internet. Seiring dengan kemajuan teknologi, komunikasi dapat berlangsung secara efektif melalui media elektronik dan internet. Hasil penelitian Panduwinata dan Lumintang (2008) menegaskan bahwa efektivitas kampanye sebagian besar dilakukan melalui media elektronik televisi dan media internet.

Awalnya KATAM dibuat dalam bentuk cetak yaitu peta kalender tanam yang memuat luas tanam dan rekomendasi sistem tanam. Sejalan dengan perkembangan teknologi KATAM 
dikembangkan dalam bentuk aplikasi yang dioperasikan menggunakan desktop dan selanjutnya berkembang terus menjadi aplikasi yang berbasis web. Sistem aplikasi KATAM terpadu yang telahberkembang pesat dari dua subsistem (aplikasiweb dan desktop) menjadi sistem yang lebihkomprehensif menjadi tujuh subsistem, yangterdiri dari aplikasi web KATAM terpadu, aplikasidesktop KATAM terpadu, aplikasi SMS center,aplikasi
Androidversi ringan, aplikasi entri datamelalui Google Drive, aplikasi desktoppemantauan KATAM, dan aplikasi web pemantauanKATAM (Ramadhani, et.al., 2015). Aplikasi KATAM berbasis web dapat diakses melalui

homepage www.litbang.pertanian.go.id seperti yang dapat dilihat pada Gambar 1.Halaman homepage sebagai jembatan untuk masuk kedalam aplikasi KATAM yaitu dengan mengklik banner kalender tanam.

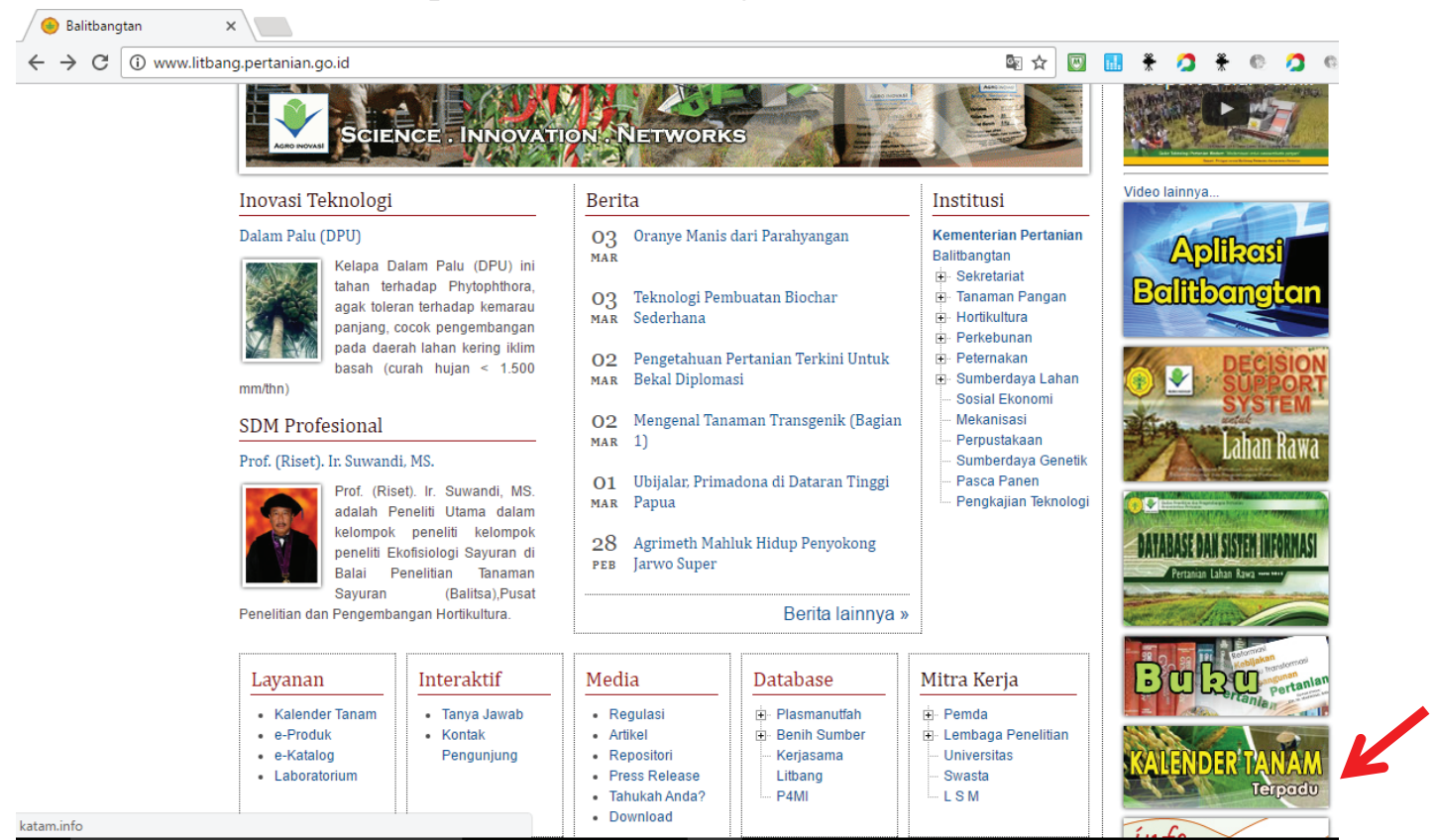

Gambar 1 Tampilan halaman homepagelitbang.pertanian.go.id

Selain melalui web, KATAM juga dikampanyekan melalui media sosial. Media Facebook merupakan media yang digunakan dalam menyampaikan informasi tentang KATAM kepada khalayak.

\section{Kepada siapa (to whom)}

Komunikasi dilakukan dengan melibatkan transaksi antara sumber dan penerima. Dalam proses komunikasi selain sumber juga harus ada yang menerima informasi. Menurut Rogers penerima informasi ini biasa disebut sebagai receiver yaitu orang yang menerima pesan dari sumber. Menurut Nimmo (2011) penerima adalah partisipan yang aktif dalam komunikasi dengan sumber.Tanpa adanya penerima pesan maka komunikasi tidak akan berlangsung dengan baik sehingga 
dengan adanya penerima maka akan timbul umpan balik yang efektif.

Dalam kasus KATAM ini, penerima pesan diklasifikasikan menjadi empat kelompok yang diidentifikasikan secara berjenjang sesuai birokrasi yang ada pada saat ini. BPTP merupakan sebagai penerima pesan KATAM pertama yang disampaikan dari Balitbangtan. Selanjutnya BPTP menyampaikan kepada penerima kedua yaitu pemerintah daerah baik tingkat provinsi maupun kabupaten/kota. Penyuluh merupakan orang yang menerima pesan dari pemerintah daerah yang selanjutnya diteruskan kepada para petani sebagai penerima pesan terakhir.

\section{Dengan akibat apa (with what effect)}

Komunikasi dalam model Lasswell dituntut adanya suatu perubahan karena bentuk komunikasi apapun dapat menimbulkan akibat (Nimmo, 2011). Menurut William J Mc Guire dalam Setiani (2007) akibat dari komunikasi dapat disamakan dengan tujuan dari komunikasi tersebut. Tujuan komunikasi menurut Berlo (1960) dalam Panduwinata dan Lumintang (2008) ada tiga yaitu :

1. Informative, suatu komunikasi yang bertujuan untuk menyampaikan ide, gagasan, rumusan pemikiran baru, perasaan dengan melakukan pendekatan pikiran. Keefektifan dapat dicapai apabila informasi yang disampaikan bersifat faktual dan obyektif.

2. Persuasive, suatu komunikasi yang bertujuan untuk menggugah perasaan seseorang dari satu situasi ke situasi lainnya atau dari tidak suka menjadi suka. Tujuan ini menggunakan pendekatan emosional.

3. Entertainment, komunikasi tipe ini bertujuan untuk menghibur atau menyenangkan orang lain melalui peragaan tertentu.

KATAM diharapkan menjadi rujukan bagi pengambil kebijakan dalam penyusunan rencana pengelolaan pertanian tanaman pangan di daerah. Kemudahan pengguna untuk mengakses data KATAMterpadu dari tingkat pusat sampai denganpetani melalui beberapa jalur komunikasidiharapkan dapat menurunkan kegagalan petaniakibat perubahan iklim (Ramadhani, et.al., 2013). Harapan ini sesuai dengan tujuan komunikasi yaitu selain memberikan informasi juga mengajak para penyuluh pertanian dan petani agar menggunakan aplikasi KATAM dalam upaya adaptasi perubahan iklim.

$$
\text { Ajakan agar penyuluh }
$$
pertanian dan petani menggunakan KATAM dilakukan melalui strategi kegiatan diantaranya adalah sosialisasi, focus group discussion (FGD), dan pendampingan. Pada saat 
melakukan pendampingan dilakukan kampanye untuk mengajak para penyuluh pertanian dan petani untuk menggunakan teknologi KATAM dalam melakukan pola tanam yang sesuai dengan rekomendasi. Kampanye dengan tema KATAM ini diharapkan dapat membantu masyarakat untuk mengubah pola pikir sehingga kemudian mengubah perilakunya terutama dalam menghadapi perubahan iklim pada saat musim tanam. Dengan demikianpenggunaan KATAM dapat meningkatkan produksi dan produktivitas tanaman pangan sehingga akan meningkatkan kesejahteraan petani.

\section{Perancangan Kampanye KATAM}

Konsep kampanye yaitu melakukan kegiatan komunikasi secara terencana yang lebih moderat, terbuka, toleran, dengan waktu terbatas atau jangka pendek, dan program yang jelas, persuasif, serta dapat diidentifikasikan secara jelas nara sumbernya (komunikator) dan selalu berkonotasi positif. Rogers dan Storey (1987) mendefinisikan kampanye sebagai serangkaian tindakan komunikasi yang terencana dengan tujuan menciptakan efek tertentu pada sejumlah besar khalayak yang dilakukan secara berkelanjutan pada kurun waktu tertentu. Merujuk pada definisi ini maka setiap aktivitas kampanye komunikasi setidaknya harus mengandung empat hal yaitu tindakan kampanyeyang ditujukan untuk menciptakan efek atau dampak tertentu, jumlah khalayak sasaran yang besar, biasanya dipusatkan dalam kurun waktu tertentu, dan melalui serangkaian tindakan komunikasi yang terorganisasi (Purwanto, 2016).

Beragam cara kampanye dilakukan, misalnya bisa melalui sebuah acara imbauan maupun penyuluhan secara langsung seperti mengadakan sebuah pertemuan seperti seminar maupun acara bakti sosial. Kampanye juga bisa dilakukan melalui media cetak maupun elektronik, kampanye pada media cetak bisa berbentuk poster, brosur, leaflet, spanduk, x-banner, iklan majalah, maupun gift (Purwanto, 2016).

Isu perubahan iklim sudah banyak menjadi bahan perbincangan di masyarakat khususnya terkait dengan pertanian. Tidak dipungkiri bahwa perubahan iklim memberikan stereotip tersendiri bagi masyarakat pertanian yaitu sesuatu yang menyeramkan dan mengakibatkan gagal panen. Oleh karena itu penyampaian kampanye harus lugas yang dibarengi dengan memberikan informasi yang tidakmembuatstress bagi penyuluh pertanian dan petani.

Rancangan kampanye harus didesain sedemikian rupa sehingga dapat menarik perhatian khalayak agar dapat menggunakan produk yang akan dikampanyekan. Dalam mendesain rancangan kampanye 
KATAM dilakukan dengan metode AISAS yang terdiri dari attention, interest, search, action, dan share.

\section{Attention}

Tujuan dari fase ini adalah untuk meningkatkan perhatian konsumen atas suatu produk. Untuk mencapai tujuan ini harus dilengkapi dengan informasi yang akurat dan lengkap tentang pangsa pasar yang ingin dituju oleh suatu organisasi. Dengan adanya internet maka pemilihan mempromosikan produk dapat dilakukan melalui cara yang relatif murah seperti email, milist, hingga iklan di media online.

Balitbangtan sebagai institusi pemerintah yang menghasilkan inovasi teknologi KATAM telah membuat fasilitas email dan SMS center untuk memperkenalkan KATAM kepada masyarakat. Email yang digunakan untuk berkomunikasi terkait dengan KATAM yaitu humas@litbang.pertanian.go.id.

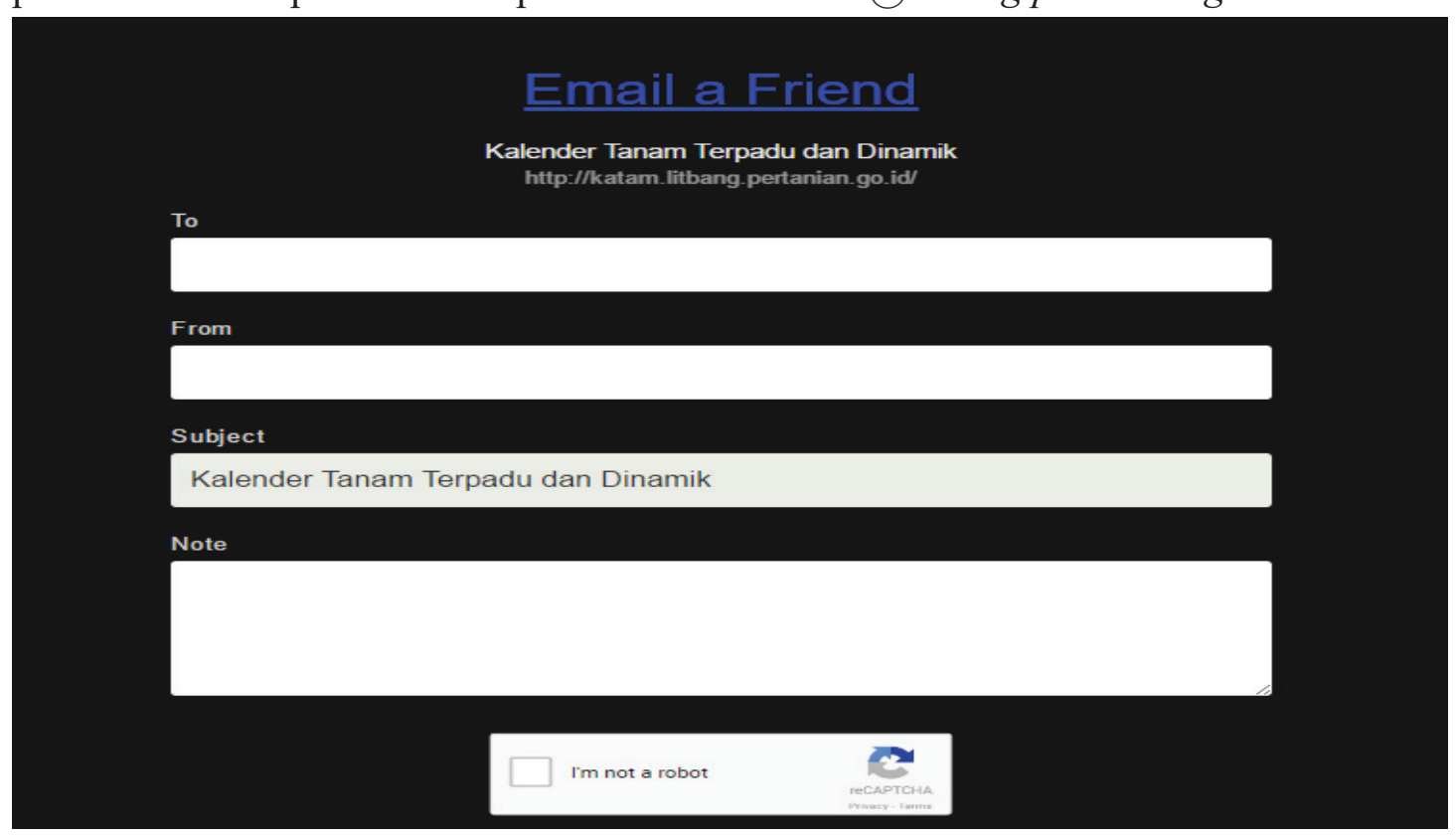

Gambar 2 Fasilitas email pada aplikasi KATAM

\section{Interest}

Interest merupakan tahap selanjutnya setelah konsumen mulai tertarik dengan suatu produk yang ditawarkan. Ketertarikan tersebut dapat terjadi karena timbul proses komunikasi dua arah yang tepat bagi calon konsumen. Pada era internet ini, ketertarikan konsumen juga dapat dilihat pada desain situs web yang menimbulkan daya tarik tersendiri. Oleh sebab itu suatu organisasi harus dapat membuat dan menyusun suatu situs yang baik sesuai dengan tujuannya dan mampu membangun pengalaman yang tepat, nyaman, menyenangkan, dan meningkatkan ketertarikan konsumen pada produk (Puspita, 2012).

Pada kasus KATAM, sebagai suatu organisasi, Balitbangtan telah 
mendesain sedemikian rupa situs web khusus untuk KATAM agar dapat dimanfaatkan oleh pengguna atau khalayak terutama para penyuluh pertanian dan petani. Dengan adanya aplikasi KATAM, banyak calon konsumen yang telah mengunjungi situs ini. Selama periode Januari-September 2012, tercatat rata-rata 60 pengunjung per hari (Ramadhani, 2013). Situs web KATAM dapat diakses melalui katam.litbang.pertanian.go.id seperti yang terlihat pada Gambar 4 berikut:

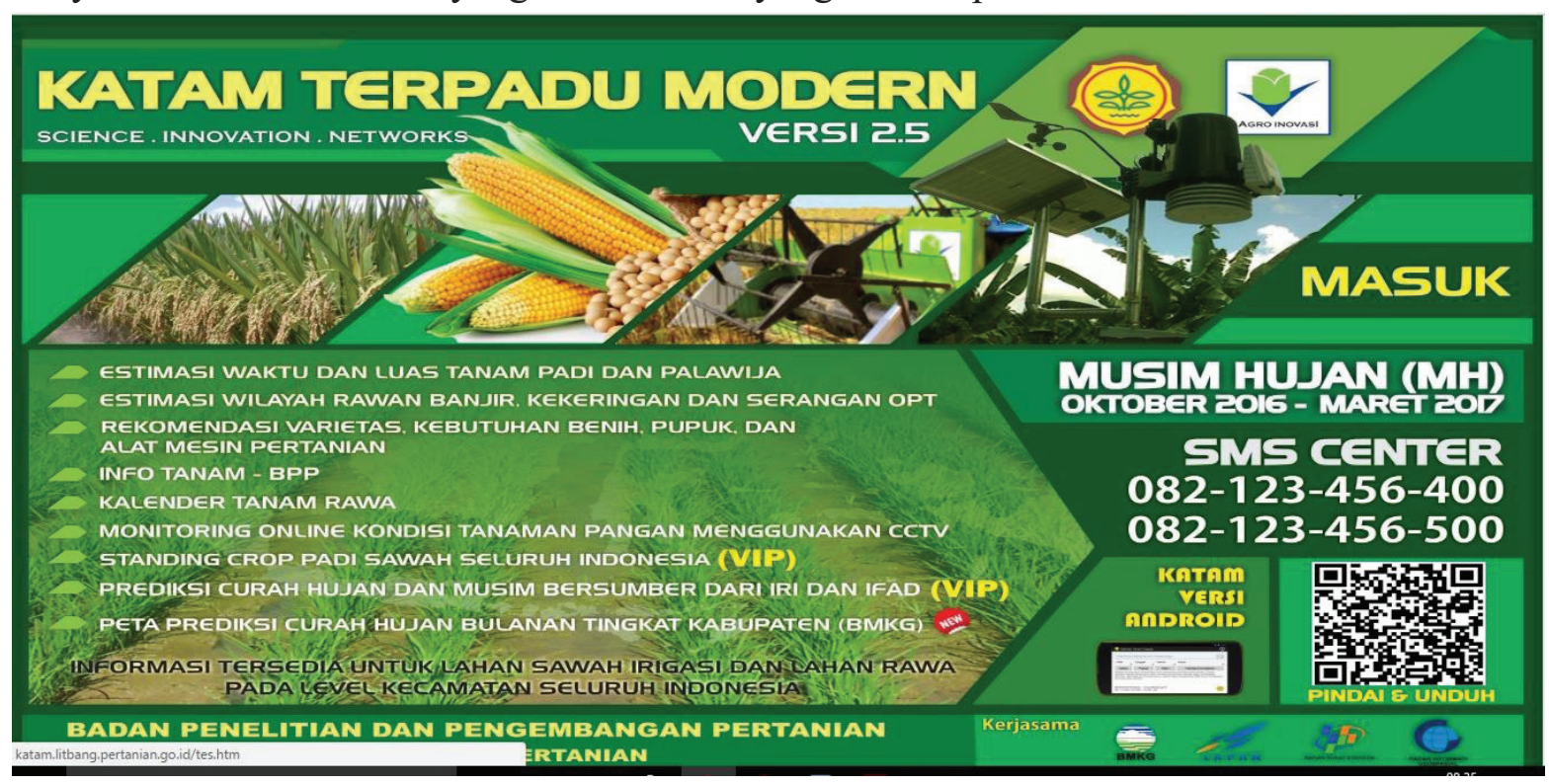

Gambar 3 Tampilan halaman depan situs katam.litbang.pertanian.go.id

\section{Search}

Search merupakan suatu proses dimana konsumen akan berusaha mencari informasi sebanyakbanyaknya melalui search engine sebelum menentukan suatu keputusan. Tinjauan tentang suatu produk tertentu dapat dipampang pada internet melalui berbagai macam bentuk seperti Facebook, Twitter, YouTube, dan Blog (Puspita, 2012).

Selain situs web KATAM, Balitbangtan juga membuat suatu media sosial untuk mengampanyekan KATAM melalui Facebook. Hal ini disebabkan banyak masyarakat yang sudah menggunakan media sosial Facebook untuk berkomunikasi. Media sosial Facebook KATAM dapat dilihat pada Gambar 3 . Disamping itu, YouTube tentang KATAM juga banyak dibuat dan diunggah ke internet untuk mengenalkan KATAM kepada masyarakat. 


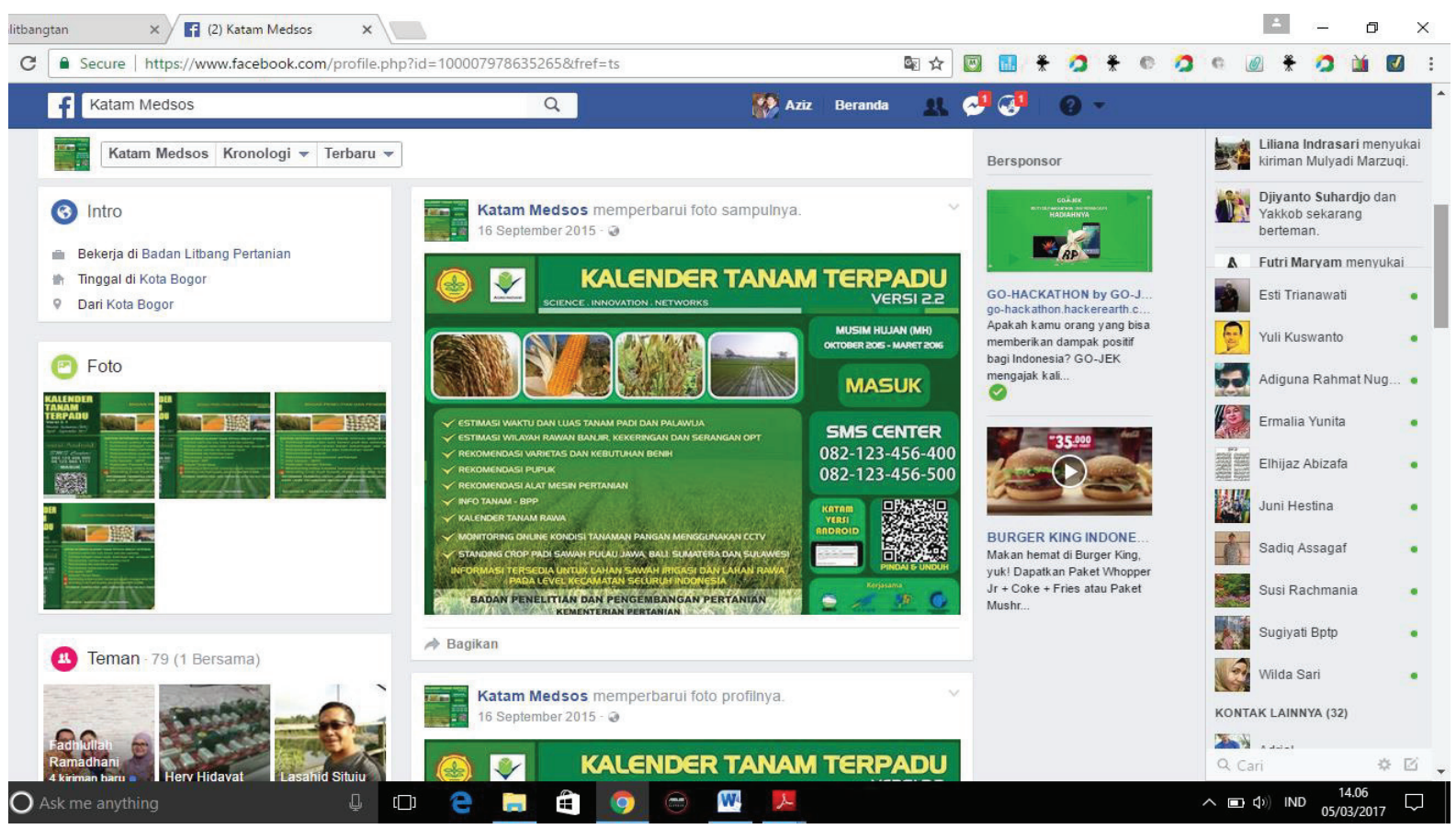

Gambar 4 Media sosial KATAM dengan menggunakan Facebook.

4. Action

Action adalah suatu tindakan konsumen dimana terdapat pengalaman yang sebenarnya dapat tercipta. Proses interaksi antara konsumen dengan semua pihak merupakan satu kesatuan yang harus dijaga dan diperbaharui secara terusmenerus sesuai dengan kebutuhan konsumen sehingga konsumen semakin percaya dan tertarik pada produk yang ditawarkan. Tujuan dari fase ini adalah agar konsumen dapat melihat langsung dan menyediakan kesempatan bagi konsumen untuk melakukan penggunaan produk dimaksud (Puspita, 2012).

KATAM sebagai produk inovasi teknologi, harus dapat disampaikan langsung kepada konsumen yaitu penyuluh pertanian dan petani. strategi penyampaian
KATAM dilakukan melalui sosialisasi KATAM, pertemuan yang fokus pada KATAM, dan workshop/lokakarya. Selai itu juga aksi nyata untuk kampanye KATAM dilakukan pada saat pendampingan KATAM.

Pendampingan merupakan bagian dari kegiatan diseminasi. Diseminasi teknologi merupakan proses timbalbalik, para pelaku menyediakan, menerima informasi dan teknologi, sehingga diperoleh kesepahaman dan kesepakatan bersama. Kegiatan diseminasi dalam pendekatan Spectrum Diseminasi Multi Chanel (SDMC), dilakukan dengan memanfaatkan berbagai jalur komunikasi dan pemangku kepentingan (stakeholders) terkait. Pendampingan dilakukan setahun dua kali pada saat musim tanam. 
Pada saat melakukan pendampingan, para pendamping mengampanyekan KATAM dengan media brosur/leaflet dan menjelaskan langsung secara lisan kepada penyuluh pertanian dan petani. contoh brosur/leaflet dapat dilihat pada Gambar 5. Disamping itu juga stiker KATAM dapat dijadikan kampanye pada saat pendampingan dengan membagikan secara gratis kepada konsumen. Contoh stiker dapat dilihat pada Gambar 6.

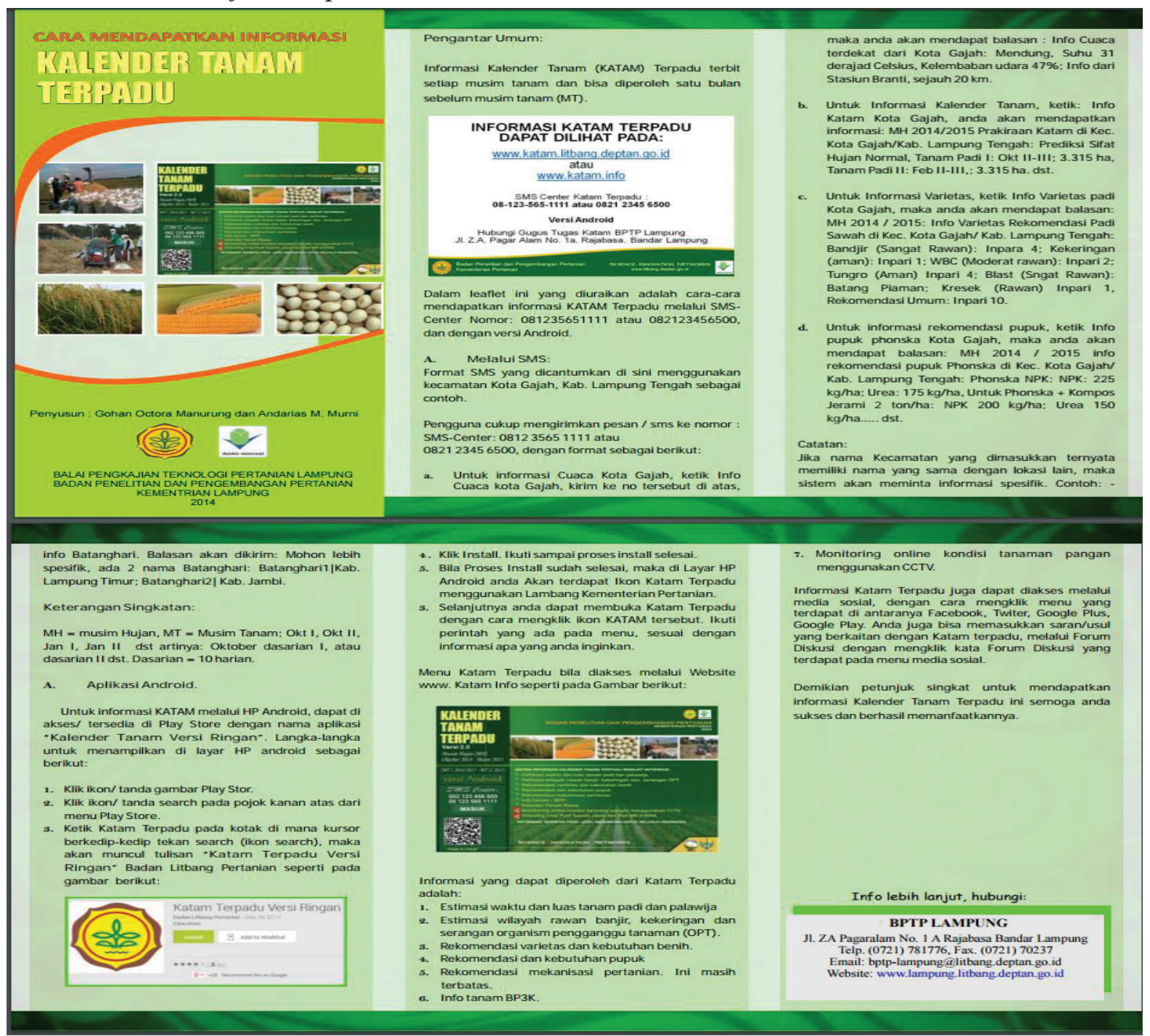

Gambar 5 Contoh brosur/leaflet tentang KATAM

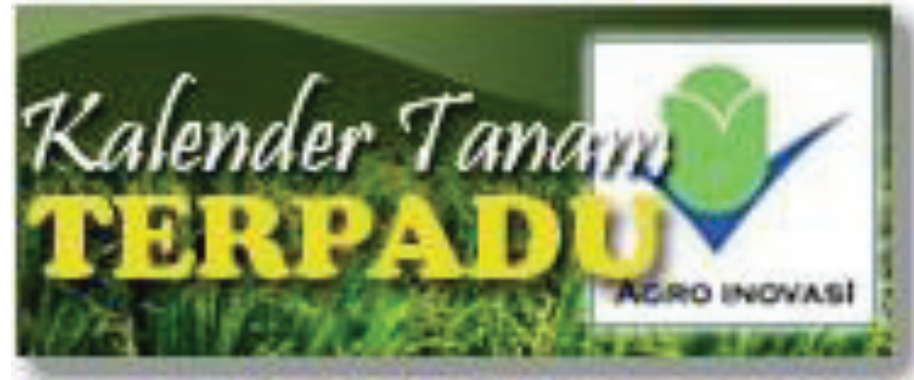

Gambar 6 Stiker KATAM 


\section{Share}

Share merupakan hasil yang akan diperoleh setelah konsumen merasakan semua pengalamannya terhadap suatu produk. Konsumen akan membagi pengalamannya kepada orang lain melalui media internet maupun media sosial. Tujuan dari fase ini agar konsumen termotivasi untuk mengirimkan informasi terkait produk dimaksud.

Bagi pengguna KATAM dari kalangan penyuluh pertanian, sebagian besar mereka melakukan transfer pengetahuan tentang KATAM kepada para petani. Transfer pengetahuan tentang KATAM dilakukan secara tradisional maupun modern. Penyampaian informasi KATAM secara tradisional dilakukan dengan cara temu lapang dengan petani. Para petani dikumpulkan di suatu tempat dan diberi penjelasan tentang KATAM dan manfaatnya. Jika penyuluh yang menggunakan telepon genggam, mereka dapat menyebarluaskan informasi KATAM ini kepada petani, teman, saudara,dan lainnya yang mereka kenal.

\section{SIMPULAN}

Berdasarkan uraian di atas, dapat disimpulkan bahwa komunikasi melalui kampanye tentang KATAM pada dasarnya sudah dilakukan oleh Balitbangtan. Kampanye ini dilaksanakan dengan menggunakan media internet dan media sosial. Kampanye KATAM ini cukup efektif karena berdampak pada banyaknya pengunjung website KATAM pada periode tertentu.

Agar lebih meyakinkan apakah kampanye KATAM benar-benar berhasil, maka perlu dilakukan kajian tentang share bagi konsumen/pengguna KATAM kepada orang lain.Berapa kali pengguna KATAM merekomendasikan kepada orang lain yang berbeda. Dengan kajian ini diharapkan semakin banyak masyarakat yang mengetahui dan menggunakan KATAM dalam adaptasi perubahan iklim.

\section{DAFTAR PUSTAKA}

Badan Penelitian dan Pengembangan Pertanian [Balitbangtan]. 2015. Laporan Tahunan 2015 : Inovasi Pertanian Bioindustri menuju Kedaulatan Pangan dan Kesejahteraan Petani. Jakarta: Balitbangtan.

Effendy, Onong Uchjana, 1993. Peranan Komunikasi Massa Dalam Pembangunan, Yogyakarta: Gadjah Mada University

Hadiyati, E. 2011. Kreativitas dan Inovasi Berpengaruh terhadap Kewirausahaan Usaha Kecil. Jurnal Manajemen dan Kewirausahaan 13 (1) : 8-16.

Kementerian Pertanian [Kementan]. 2015. Peraturan Menteri Pertanian Nomor 43/Permentan/OT.100/8/2015 tentang Organisasi dan Tata 
Kerja Kementerian Pertanian. Jakarta : Kementan.

Kushartanti, E., et.al. 2013. Sosialisasi, Verifikasi, Validasi, dan Umpan Balik Kalender Tanam di Jawa Tengah.

http://jateng.litbang.pertanian.g o.id/ind/images/produk/hasilpe ngkajian/2013/soskatam.pdf. Diakses pada 23 Januari 2017. Mulyana, 2000. Pengantar Ilmu Komunikasi. Bandung:Remaja Rosdakarya

Nimmo, D. 2011. Komunikasi Politik: Komunikator, Pesan, dan Media. Bandung: PT Remaja Rosdakarya.

Panduwinata, G.G.E. dan Lumintang, R.W.E. 2008. Faktor-faktor yang mempengaruhi efektivitas program public awareness : studi kasus kampanye flu burung oleh Badan Karantina Pertanian di Jakarta. Sodality : Jurnal transdisiplin sosiologi, komunikasi, dan ekologi manusia 2 (3) : 347 - 360 .

Purwanto, T. 2016. Laporan Akhir : Perancangan Kampanye Bahaya Efek Blue Film terhadap Otak. Bandung : Universitas Pasundan.

Puspita, R.A.C.C. 2012. Rancangan Program Kampanye Komunikasi Pemasaran dengan Konsep AISAS : Studi kasus pada Prenagen Esensis. Tesis.
Jakarta : Fakultas Ekonomi, Universitas Indonesia.

Ramadhani, F., Eleonora, R., Haris, S. 2013. Sistem Teknologi Informasi Kalender Tanam Terpadu. Informatika Pertanian 22 (2) : 103-112.

Ramadhani, F, Haris, S., Eleonora, R. 2015. Aplikasi Android pada Sistem Informasi Kalender Tanam Terpadu. INKOM 9 (1) : 39-44.

Rogers, Everett M dan Shoemaker, F Floyd, Komunikasi Sambung Rasa, Jakarta, Pustaka Sinar Harapan : 1981.

Ruslan, R. 2000. Kampanye Public Relations. Jakarta : PT. Raja Grafindo Persada

Runtunuwu, E., et.al. 2013. Inovasi Kelembagaan Sistem Informasi Kalender Tanam Terpadu mendukung Adaptasi Perubahan Iklim untuk Ketahanan Pangan Nasional. Pengembangan Inovasi Pertanian 6 (1) : 44-52.

Sarwani, M. dan Syahbuddin, H. 2013. Memantapkan Langkah dan Strategi Pengembangan SI Katam Terpadu dalam Menyikapi Perubahan Iklim. Jakarta : IAARD Press.

Setiani, Y. 2007. Kampanye dalam Merubah Sikap Khalayak. Bandung : Fakultas Ilmu Komunikasi UNPAD

Zubaidah, S. 2015. Analisa Kebijakan Nawa Cita No.6 JK $V / S$ Pengembangan 
Agroindustri Peternakan

Berkelanjutan Berbasis Sapi

Lokal dalam Pengembangan

Perekonomian Masyarakat dan

Daerah

Propinsi
Aceh.https://www.academia.ed u/10609480/Analisa_Kebijaka n_Nawa_Cita_Jokowi_-_JK.

Diakses pada 1 Februari 2017. 